\title{
ORALITY, MEMORY AND THE NEW AFRICAN DIASPORA POETRY: EXAMINING TANURE OJAIDE'S POETICS
}

\author{
Edoama Frances Odueme \\ University of Lagos, Nigeria
}

\begin{abstract}
The influence of traditional oral poetic forms on modern African poetry has been significant. Fascinated by oral forms which their respective communities relied on (to inform, teach, and correct erring members) before the advent of literacy, modern African writers borrow from these oral traditions and blend them with the features of the written Western literary forms. This appropriation of the oral poetic techniques by modern African poets continues today, as is clearly evident in the writings of many contemporary African poets, whose scripted works are seen to have drawn much in terms of content and form from the African oral poetic tradition. Following in this trend, the new African diaspora poets have also maintained the practice of skillfully blending the rich African verbal art and the modern (written) poetic forms to articulate the experiences of their African homeland as well as those of the diaspora, in order to construct and project their identities and visions of a new life in their lived world. In order to explore how through recourse to memory, "new African diasporas" (African-descended people who migrated out of Africa, during the postcolonial era and who live and practice their art outside the African homeland) utilize African oral art techniques in their writings, this essay analyses the poetry of Tanure Ojaide.
\end{abstract}

KEYWORDS: ORALITY, ORAL TRADITION, MEMORY, NEW AFRICAN DIASPORA

\section{Introduction}

African oral poetry, as a dynamic art form, is an ingenious genre that permeates the African people's experiential life. It is a literary poetic form that exists mainly in memory from where it is transmitted from one generation to the other, through narration or by word of mouth. Charles Bodunde describes African oral art as a "complex corpus of verbal or spoken art" which he says consists of "ideas, beliefs, symbols, assumptions, attitude and sentiments of peoples"; and is brought into being as a means of recreating the past (24). The African oral poetic form which is conceptualized primarily in the mind, memorized or retained and retrieved when the need arises, is esteemed for its transmission of values through entertainment. But in addition to its aesthetic uses, it is also exploited for its didactic function. Conscious of the need to sustain the functional role of the oral poetic art in the written art form, writers of modern African poetry, adopt elements of the traditional poetic art techniques and skillfully fuse these into the creation of their scripted pieces. This essay thus examines how memory impacts Ojaide's poetry as he employs the rich traditional Urhobo oral heritage to inscribe his experiences, feelings and thoughts on the 
contemporary realities, while living in the diaspora. The poetic reference for this essay will be taken from three of Ojaide's poetry volumes: Daydream of Ants and Other Poems (1997), When It No Longer Matters Where You Live (1997), In the House of Words (2006). These volumes are selected to facilitate the illustration of the poet's sustained trust on the African traditional oral poetic tropes over time (from early periods to the later years in the diaspora), to aid him in creating poetic pieces that convey to his audience the creative representation of the experience of inhabiting multiple locations. In analysing the selected texts, the study utilizes Carol Boice Davies's theoretical reflections on "diaspora memory", to show in the context of selected poems, how memory aids the literary creative imagination of African diaspora writers, even in the contemporary period.

Ojaide is a modern African (Nigerian) poet whose writing career spans the different periods and sites of his settlement (his African homeland and the diaspora). As one of the leading literary artists of the new African diaspora - the African descended people who migrated out of Africa during the postcolonial era - who live and practice their art outside the African homeland, Ojaide is heir to the multi-literary traditions - precolonial and postcolonial. Critics have noted that the poet consciously incorporates the elements of oral poetic form (especially those of his immediate Urhobo traditions, through which he obtained his early childhood training), into his poetic art, to give it some form of African identity. Enajite Ojaruega observes that Ojaide's utilization of orature in his writings helps him to establish a cultural identity as it also helps him organise the style of his works, which in turn, aid the adept expression of his desired themes ${ }^{1}$. Similarly, Ogaga Okuyade in his study, notes that Ojaide employs the elements of oral poetry to highlight his relatedness to his place (of origin) as he expresses his sense of individual and collective identity ${ }^{2}$. Writing on the influence of Urhobo folklore on Ojaide's poetry, Mathias Iroro Orhero also remarks that Ojaide' poetry has been largely inspired by the "subtext of Urhobo folklore", which he says forms the source of his themes and techniques (4).

Although Ojaide's diaspora poetry, like the pieces he wrote while living at home in Africa, reflect his various life experiences (those of his years in his native homeland and of his sojourn in the diaspora), his childhood memories remain the taproot from which he draws his inspiration, and this manifests in the content and the form of his writings. The poet himself maintains that with his poetic art, he represents the "contemporary minstrel" who in addition to being a public figure, a traveler and an observer of humanity, is also one who is grounded in the landscape and fate of his native land and people. ${ }^{3}$ In his critical essay, "I Want to Be an Oracle: my Poetry and My Generation", the poet also unequivocally restates the source of the rich poetic materials on which he depends, for his literary art. He asserts:

1 Enajite Eseoghene Ojaruega. "The Place of Urhobo Folklore in Tanure Ojaide's poetry.” Tsydkrif Vir Letterkunde, 52.2 (2015): 138. Web November 2016.

2 Ogaga Okuyade, “Aesthetics Metamorphosis Oral Rhetoric in the Poetry of Tanure Ojaide.” Focus in Nigerian Literature and Culture. ed. Gordon Gollier, 40 (2012): 34-50. Web January 2018.

3 Tanure Ojaide, Charlotte Papers in African Studies no. 5 (2013) ed. Akin Ogundiran, A Publication of Africana Studies Department. 
To me, as a poet, childhood is vital, because it is the repository of memory. That is why the Delta area has been so important to me. I had quite an extraordinary youth, which still bubbles in my memory and writing... My Delta years have become the touchstone with which I measure the rest of my life. The streams, the fauna, and the flora are the symbols I continually tap. Even when I wander outside to the many places I have experienced, that land of streams, the iroko tree, antelopes, anthills and so much life remains indelible in my memory and imprinted in my thought (Poetic imagination 122).

Thus, drawing from memory, the poet re-enacts the oral traditions, using the techniques inherent in the shared cultural narratives and traditional poetic/dramatic performances of his native homeland, as evident in his written works. The hybridized text which results from the fusion of elements from different literary traditions, typifies the interaction of manifold cultures in contact, consequent upon the diverse experiences of the poet.

Carol Boice Davies' study on "Afro-Diasporic Culture, and the Literary Imagination" on which this study bases its analysis, deals extensively with the inter-relatedness of "diaspora memory" and the imaginative recreation of the existential realities of the lives of Africans in the diaspora. Boice Davies conceives of diaspora memory as a concept that entails the deliberate attempt to reinterpret "remembered cultural forms in a new space and in new conditions" (200). But in her further elaborations of the precept of the concept, she stresses the extemporaneity of diaspora memory; maintaining that recollection of the memorized cultures by African diaspora does not equal a "romanticized or essentialized" memory of Africa but reinterpretations and recreations of African cultures based on contemporary experiences (208). Diaspora memory to her, signifies the abilities to hear one's inner, silent voices (214). Boice Davies avers that through diaspora memory, the African diaspora writer, is able to reconstruct myths. legends, folklore or history, sometimes weaving together several elements into one fabric (216/217).

Scholars have observed the prominence of diaspora memory in the imaginative writings of Africans in the diaspora, spanning the different phases of the African diaspora. Paul Zeleza remarks that it is the invocations of memories of cultural norms and practices that have sustained and aided the artistic representation of cultural "genealogy" of Africans living in the diaspora (47). Tayo Olafioye (138) and Sayed Sadek (91) have noted the prevalence of memory in Ojaide's writings, which according to them, aids the poet's imaginative recording of experiences, using the internalised elements of African oral poetic forms. In examining Ojaide's appropriation of his native Urhobo oral art techniques in his poetry, while residing outside his native homeland, this paper explores the impact of diaspora memory on his writings.

\section{Orality and Memory in Tanure Ojaide's Diaspora Poetry}

From a critical examination of the poems in the aforesaid collections of poetry, it is evident that the poet maintains a continuous communion with the memory of the cultural practices of his place of origin, as he deploys a number of parables, symbols, images, 
metaphors and many other oral poetic devices from his native homeland. Boice Davies posits that diaspora memory awakens the desire to recall the experiences "of other more amicable worlds" (214). As observable in the poems "Memory Dispels Rumours" and "The Script of Fate", Ojaide recreates the image of a harmonious homeland by imagining his past experiences, recounting the rich cultural heritage of his birthplace (the moments and scenery, the flora and fauna), that characterize the peaceful ambience of his homeland. In the former poem, the poet's longing for familiar forms and codes aids his recollection. He recounts how the "articles for human upkeep are retrieved", or stories of childhood days that he thought he had forgotten "re-appear with fresh voices" and how "all that seem lost falls back / into the pathway of enquiry, / bound to be tripped over / and picked for a discovery (Daydream of Ants 17). In the opening lines of the poem, the poet's ample use of aphorisms and parables, elements derived from the traditional oral repertoire of his Urhobo origin, to express his nostalgic feelings, are apparent:

A thread tugs me from time-lit caves;

it reaches back where

rivers made their beds without water, trees touched the sky with wet fingers...

And there's access to times

beyond seas and mountains... (17).

In the latter poem, "The Script of Fate", following the story-telling pattern of oral poetry, Ojaide continues to draw from memory to enliven his sojourn in a new and an unfamiliar abode. His encounter with strange cultural norms and codes in the diaspora, evokes the memory of the beauty of the simple but sophisticated African traditional artistry. As far as the poet could recall, every aspect of the traditional life of his people bore the signs of instinctive African creativity. His choice of images ("skin", "forehead", "walls", "tomes of clay", etc.) to reflect the people's lifestyle illustrate this (Daydream of Ants 18).

In contrast to Boice Davies' rejection of the influence of hybridity in the recreation of homeland memories, Ojaide acknowledges the significance of the blending of different literary conventions in the practice of his poetic art, in the contemporary period, in the above-mentioned poems. In the concluding parts of both poems, the poet highlights the role of written orality in "a paper-choking world" (Daydream 18). He opines that the practise of "orature" in modern African poetry, helps in the preservation of the rich African literary culture in the postcolonial period. As the poet explains, unlike in the precolonial period when Africans could retain and retrieve these traditional forms as and when necessary, in the contemporary period their contact with other cultural norms means that most Africans have lost "faith" in their ability to do so.

To extend the illustration of his hybrid disposition, which results from his exposure to different cultural codes, Ojaide employs the image of "the eyarega grass" in his poem "Opening Song”. He equates himself with this traditional Urhobo symbol of resilience, to substantiate his credence in the irrepressibility of the African essence, which accounts for the reinterpretation of retained cultural artefacts, even in new circumstances. In the 
second section of the poem, the poet employs local aphorisms in antithetical phrases, in self-affirmation, in further articulating his hybrid identity:

Call me

fire that burns big trees

$\&$ leaves the underbrush

grass that grows wilder

the more it is cut

gun that refuses to shoot

at the antelope for beauty's sake

open-mouthed calabash

that won't drown in waves

white cockerel invisible

in the airspace of falcons

blind seer's other eye

masquerade without a mask.

I want the company I keep

to lead me word by word on the road

to the song I want raised from my lips...

(When It No Longer Matters 28-29).

Folktales which remain the major element of Urhobo oral poetry feature prominently in Ojaide's diaspora poems. Dipping into his memory, the poet extracts historical anecdotes in order to address contemporary realities. In the poems, "There's a Leopard in the Cornfield" and "Heroes", the poet appropriates the traditional folktales of the Urhobos to replicate the tale of the political conundrum in his home country.

The uncouth, rough and greedy behaviour of the political actors in the poet's country of birth could only be equated with that of the leopard, a predatory animal. In the poetic tale, the entire country and the citizens, symbolized by the farm/cornfield and farmers/hunters respectively are being stalked and ripped off by the politicians, as they use the cover of political office to pillage the peoples' commonwealth because "the stalker's spots blend with harvest colours .../ The leopard lies in wait at the corridor of power / the commonwealth distended with windfalls / the wealth is of gold .../ the republic is a farm ... / there's a leopard in the cornfield ... / harvesters and all, beware!" (In the House of Words 41-43). The use of the repeated phrase - "there's a leopard in the cornfield" - is similar to the practice of the use of repetition in an oral performance, to emphasize the significance of the information being passed to the public.

Similarly, in "Heroes", the poet looks back in time, to recreate the Urhobo history and folklore. Through the use of legendary figures, Ogidigbo and Ikoikpokpo (Daydream 72), he expresses his concerns on contemporary challenges facing his home country. The poem is a poetic re-enactment of civil confrontations in the folkloric bequest of Urhobo oral tradition. The poet uses the characters of Ogidigbo as a metaphor for the tyrant leaders, while Ikoikpokpo symbolizes the upright, courageous and fearless youths who stand up against 
the devious antics of the despotic rulers. The aim of reconstructing this episode is to draw the necessary lesson from history in order to give the people, especially the younger generation an insight into how to confront prevailing societal challenges (in a non-violent manner), in the contemporary period. The poet's practice accords with Ojaruega's observation that Ojaide employs memory in his writings, in what she describes as "the art of imagining back", and which she says provides the poet the opportunity of using symbols, images and mythical and historical characters that have parallels with current events to reflect on the contemporary socio-political situation (138). Thus, just as the poet recalls from memory the tender moments and pleasant atmosphere of his birthplace, experiences in the diaspora also evoke unpleasant memories in the mind of the poet.

In many of his poems, Ojaide affirm Boice Davies' belief that in diaspora memory, the desire for the physical location does not count as much as the aesthetic desire of the preferred homeland. In his poem, "Simple Songs", Ojaide illustrates this. Through the use of symbolism, he relays how, in spite of his supposed life of luxury in the diaspora, his longing for his homeland is rekindled by the need to keep alive the resourceful values which the place holds for him, and how his memory comes to his aid, in keeping him connected with the original source of his creativity.

In a simple stroll to shake off boredom, the minstrel enters an enchanting garden.

He listens to birds courting, nods at

flowers marvelous without makeup...

He walks barefoot unhurt through thorns

in the rancour-free multiethnic nation.

In the timeless sojourn in another state,

his body bristles with health and peace...

He trips again; this time from daydream

falling straight into the arms of the muse

who takes him into the house of open words

where he now entertains with simple songs (1).

The poem, "Diviner's Chant", further illustrates Ojaide's bond with his homeland. The artistic values which the poet derives from such continued attachment is articulated in the poem. Although the poet expresses his dissatisfaction with state of affairs in his homeland, he holds on to the memory of the place, as he also makes use of the native land's creative resources. In a manner similar to that of a chief priest in an oral performance (who delivers ordinances and guidelines to his people), the poet intones his admonition - unmasking and reproaching the various groups of people in his home country, who under different guises swindle and rip-off members of the general public. The repeated use of "I" (Daydream 48 ), in the poem produces an impression of an oral poet or cantor who puts his clairvoyant skills on display as he addresses the audience in a public presentation. He predicts a woeful end for these groups, if they do not desist from their devious ways and foretells the doomsday that will befall the leaders that engage in these unscrupulous acts. 
In "Accents", Ojaide enumerates some of the aesthetic values he derives from remaining constantly connected to his birth place, through memory. There is a nostalgic recollection of the tender moments and seasons which he cannot take part in, on the account of his estrangement from his homeland.

My heart breaks

for the crow of

the returning road.

Memories of festival music

relax my muscles...

In the half light

of a recurring dream,

a woman with eyes

flaring with tenderness

always confronts me:

"When will you come,

walk through the slums,

jump over the gutters,

and embrace me as yours?

I only live for you"

When I wake, my face

wet from drowning,

I long for days

that break on a plateau (When It No Longer Matters 17).

In this poetic narrative, the poet recounts the haunting moments and the beautiful things he left behind as he employs the poetic-dialogue inherent in the story-telling tradition of the Urhobo oral art.

Ojaide's outright adoption of the folksong of his people, in the poem, "America Wonder", reveals the poet's belief in the efficacy of the oral poetic aesthetics in conveying the intended messages. The poem is a metaphorical expression of the poet's displeasure and disgust at the trickery and deceit of the home country's ruling class. He appropriates the term, "America wonder" which is used to describe things that somewhat defy explanation, to depict the treachery and misrule in his country of origin. He croons:

Come and see America wonder

Come and see America wonder

Come and see America wonder

Come and see America wonder

The local magician in my primary schooldays sang

"America wonder" before pulling off a hard trick

Come and see America wonder

Come and see America wonder

The cake disappeared from a closed fist. 
A simple thread turned into a silk scarf.

Come and see America wonder

Come and see America wonder

Ojaide's poetry bears witness to the effectiveness of memory in aiding the recollection, reinterpretation and recreation of his past and present experiences. The poet also demonstrates in his writings his unbroken bond with his birthplace as he efficiently employs the African oral poetic elements in the inscription of contemporary realities, in his new place of abode.

\section{Conclusion}

Determined to ensure the relevance of his creative pieces, Ojaide, like most contemporary African literary artists in the diaspora, allows himself to be guided by his childhood memories of the rich African oral tradition of his homeland. The poet makes use of several oral techniques such as anecdotes, dialogue, folktales (that sometimes make use of animals and plants as characters), proverbs, myths and riddles, borrowing heavily from this rich repertoire of African oral art forms, to enrich his scripted experiences. Through this practice, the functional role for which the African oral or verbal art exists,- to uphold the common good of the society - is always skillfully crafted into his literary pieces. With recourse to memory, the poet continues to hold on to the desire of creating functional poetic pieces that impact the lives of his people, irrespective of his new place of residence. He elects to fuse the elements of African oral art with his written pieces to give his creative works the desired vibrancy, as demonstrated in his collections.

\section{References}

Bodunde, Charles. “Oral Traditions and Modern Poetry: Okot p’Bitek’s Song of Lawino \& Okigbo’s Labyriths”. African Literature Today, 3 (1992): 24-34. Web August, 2016.

Davies, Carol Boice. Transformational Discourses, Afro-Diasporic Culture, and the Literary". Macalester International 3.20 (1996): 199-218.

Ezenwa-Ohaeto. "Orality and the Craft of Modern Nigerian Poetry: Osundare's Waiting Laughters and Udechukwu's What the Madman Said'. African Languages and Cultures 7.2 (1994): 101-119. Web August 2016.

Ogundiran, A Publication of Africana Studies Department, 5 (2013): 1-30. Web: December 2016.

Ojaide, Tanure. Daydream of Ants and other Poems. Lagos: Malthouse, 1997. Print.

- When it no Longer Matters Where You Live. Calabar: UP, 1998. Print

— In the House of Words. Lagos: Malthouse, 2006. Print.

— "The Beauty I have Seen" in Charlotte Papers in Africana Studies. Ed. Akin

Ojaruega, Enajite Eseoghene. "The Place of Urhobo Folklore in Tanure Ojaide's poetry." Tsydkrif Vir Letterkunde, 52.2 (2015): 138. Web November 2016.

Olafioye, Toye. The Poetry of Tanure Ojaide: A Critical Appraisal. Lagos: Malthouse Press, 2000. Print.

Okuyade, Ogaga. "Aesthetics Metamorphosis Oral Rhetoric in the Poetry of Tanure Ojaide." Focus in Nigerian Literature. Ed. Gordon Goiler, 40 (2012): 34 -50. Web: January 2018. 
Orhero, Mathias Iroro. "Urhobo Folklore and Udje Aesthetics in Ojaide's In The House Of Words and Songs Of Myself." Comparative Literature and Culture 19.2 (2017): 1-10. Web: January 2018.

Sadek, Sayed. "The Homeland as a Lost Paradise: Postcolonial Aspects in Selected Poems by Tanure Ojaide". European Scientific Journal 19.35 (2013): 88-104. Web July 25, 2014.

Zeleza, Paul Tiyambe. "Diaspora Dialogues Engagements Between Africa and Its Diaspora." In The New African Diaspora. Eds. Okpewho, Isidore and Nzegwu, Nkiru. Bloomington: Indiana UP, 2009. Print 31-58. 
